\title{
Effects of removal of the forestomach and caecum on the utilization of dietary urea in golden hamsters (Mesocricetus auratus) given two different diets
}

\author{
BY EI SAKAGUCHI, JUNICHI ITOH*, HISASHI SHINOHARA† AND \\ TATSURO MATSUMOTO
}

Faculty of Algriculture, Tohoku University, Sendai 980, Japan

(Received 12 January 1981 - Accepted 23 June 1981)

1. Surgical removal of the forestomach, the caecum or both the forestomach and the caecum, was performed on growing male golden hamsters (Mesocricetus auratus) given a low-or high-fibre diet.

2. In Expt 1,18 d after surgery, the hamsters which were given a concentrate before surgery were given an experimental low-fibre diet containing urea or $\left[{ }^{15} \mathrm{~N}\right]$ urea $(10 \mathrm{~g} / \mathrm{kg}$ diet) for $9 \mathrm{~d}$. In Expt $2,5 \mathrm{~d}$ after surgery, the hamsters which were given a foragi diet before surgery were adapted to an experimental high-fibre diet containing urea $(10 \mathrm{~g} / \mathrm{kg}$ ) and dried Italian ryegrass (Lolium italicum) powder $(400 \mathrm{~g} / \mathrm{kg}$ diet) for $5 \mathrm{~d}$, and $10 \mathrm{~d}$ after surgery, given a diet containing [ $\left.{ }^{1} \mathrm{~N}\right] \mathrm{urea}(10 \mathrm{~g} / \mathrm{kg}$ diet) for $9 \mathrm{~d}$.

3. In both experiments, removal of the caecum resulted in a significant lowering of both weight-gain and the digestibility of the dry matter, and removal of the forestomach resulted in a significant decrease of both accumulation of ${ }^{15} \mathrm{~N}$ in the body grotein and proportion of ${ }^{15} \mathrm{~N}$ retained in the body protein as a proportion of the administered dosage.

4. The effect of removal of the caecum on the utilization of $\left[{ }^{15} \mathrm{~N}\right]$ urea was not apparent in Expt 1 , but the utilization of $\left[{ }^{15} \mathrm{~N}\right]$ urea was significantly lowered by removal of the caecum in Expt 2 .

5 . These results suggest that the caecum may play a more important role in food utilization than the forestomach. However, the forestcmach of the golden hamster plays a significant role in the utilization of dietary urea. It is presumed that the role of the caecum in the utilization of urea may vary under different dietary conditions.

The golden hamster (Mesocricetus auratus) possesses a distinctly compartmentalized stomach which consists of a forestomach and a glandular stomach. In the forestomach, great numbers of protozoa and bacteria are found (Kunstyr, 1974; Imai et al. 1976), and production and absorption of volatile fatty acids (VFA) have been demonstrated (Hoover et al. 1969). Recently, Bania et al. (1975) indicated that the hamster is less dependent on the quality of dietary protein than the rat. Manda \& Takano (1976) reported that hamsters digested a considerable amcunt of dry matter (DM), energy, cell-wall constituents and crude protein (nitrogen $\times 6.25$ ) of fresh legumes, and survived and gained weight when they were fed on fresh legumes, without any supplementation. Furthermore, a significant correlation between the forage digestibilities of hamsters and sheep was demonstrated by Manda (1979). Tseng et al. (1976) indicated that feeding of inorganic cobalt to the hamster prevented almost all the metabolic changes due to vitamin $B_{12}$ deficiency. These studies suggest that the hamster possesses ruminant-like nutritional characteristics, and that the microbiological activities of the forestomach may contribute to the nutrition of the hamster.

Matsumoto (1955) has shown that the hamster is capable of utilizing urea-N under conditions in which there i: none by the rat. In a previous paper (Sakaguchi et al. 1978), the authors reported that dietary urea- $\mathrm{N}$ was utilized for protein synthesis. The following experiments were conducted to study the effect of surgical removal of the forestomach, the caecum or both the forestornach and caecum, on dietary urea utilization by hamsters given two different diets.

* Present address: Fukushima Prefectural Office, Fukushima 960, Japan.

$\dagger$ Present address: Nasusanroku Dairy Co-operation, Kuroiso 325, Japan. 
MATERIALS AND METHODS

\section{Expt 1 \\ Animals and feeding}

Random-bred, 30-d-old, male hamsters were allocated to the following four groups, each containing six animals: control (sham-operated; group S), forestomach removed (group F), caecum removed (group $\mathrm{C}$ ), both forestomach and caecum removed (group F $+\mathrm{C}$ ).

After surgery hamsters (30-d-old), were housed in $300 \times 340 \mathrm{~mm}$ cages in groups of four or five for $18 \mathrm{~d}$. The animal room was maintained at a constant temperature of $23 \pm 1^{\circ}$. A $14 \mathrm{~h}$ light $-10 \mathrm{~h}$ dark cycle was automatically maintained, the light period being between 06.00 and 20.00 hours. At $18 \mathrm{~d}$ postsurgery, the animals were housed individually in $150 \times 200 \mathrm{~mm}$ wire-bottom metabolism cages for $9 \mathrm{~d}$. During this period, the body-weight and food consumption were recorded daily. Faeces were collected daily during the last $5 \mathrm{~d}$.

On the morning of the last day of the experimental period ( $27 \mathrm{~d}$ after surgery), all hamsters were anaesthetized with diethyl ether, and slaughtered by decapitation. Blood was taken into a heparinized syringe and immediately centrifuged $(1500 \mathrm{~g}, 15 \mathrm{~min})$. The livers, kidneys and alimentary tracts were weighed and carcasses were immediately stored at $-20^{\circ}$ before assays were made.

The hamsters were given a commercial cubed diet (F-1 ; Funabashi Farm Inc., Funabashi, Japan) ad lib. from weaning (2l-d-old) to surgery (30-d-old). After surgery, hamsters were given the same diet as before surgery for $18 \mathrm{~d}$ ad lib. F- 1 contained $(\mathrm{g} / \mathrm{kg}) 213$ crude protein $(\mathrm{N} \times 6.25), 56$ crude fat, 33 crude fibre, 57 crude ash and $571 \mathrm{NFE}$. From $18 \mathrm{~d}$ after surgery, the hamsters were given the experimental diet ad lib. for $9 \mathrm{~d}$. The experimental diet was a purified diet containing $10 \mathrm{~g}$ urea $/ \mathrm{kg}$ (see Table 1). The diet was analysed for crude protein, which was found to be $97 \mathrm{~g} / \mathrm{kg}$. Three of six hamsters, which had body-weights of approximately the mean of their respective groups, were given [ $\left.{ }^{15} \mathrm{~N}\right] \mathrm{urea}(15.2$ atom $\%)$ in exchange for non-labelled urea.

Table 1. Composition $(\mathrm{g} / \mathrm{kg})$ of experimental diets

\begin{tabular}{|c|c|c|}
\hline Expt no. & 1 & 2 \\
\hline Italian ryegrass* (Lolium italicum) & - & 400 \\
\hline Maize starch & 530 & 383 \\
\hline Sucrose & 200 & 50 \\
\hline Casein & 80 & 64 \\
\hline Soya-bean oil & 50 & 40 \\
\hline Cellulose & 50 & - \\
\hline Vitamin mix ${ }^{\dagger}$ & 20 & 20 \\
\hline Mineral mix & $60 \ddagger$ & $33 \S$ \\
\hline Urea ([15 N]urea) & 10 & 10 \\
\hline
\end{tabular}

- Early bloom, oven-dried hay.

† Vitamin mix: retinol $12 \mathrm{mg}$, cholecalciferol $200 \mu \mathrm{g}$, tocopherol $10 \mathrm{mg}$, thiamin $79 \mathrm{mg}$, pyridoxine $39 \mathrm{mg}$, riboflavin $159 \mathrm{mg}$, Ca-pantothenic acid $258 \mathrm{mg}$, nicotinic acid amide $344 \mathrm{mg}$, choline $500 \mathrm{mg}$, pteroylmonoglutamic acid $5 \mathrm{mg}$, biotin $1 \mathrm{mg}$, hydroxocobalamin $0.2 \mathrm{mg}, \psi$-inositol $1.176 \mathrm{mg}$, ascorbic acid $588 \mathrm{mg}$, menadione $16 \mathrm{mg}$.

$\ddagger$ Harper (1959).

$\S$ Mineral mix: $\mathrm{CaHPO}_{4} .2 \mathrm{H}_{2} \mathrm{O} 65.2 \mathrm{~g}, \mathrm{NaHCO}_{3} 11.2 \mathrm{~g}$, Harper's (1959) mineral mix $23.6 \mathrm{~g}$.

\section{Surgery}

For surgery the hamsters were anaesthetized with an intraperitoneal injection of sodium pentobarbital (Abbott Laboratories, North Chicago, Ill. 60064, USA), using a dose of $100 \mathrm{mg} / \mathrm{kg}$ body-weight. The incision area was washed with ethyl alcohol $(700 \mathrm{ml} / \mathrm{l})$. 
Removal of forestomach. A small $15 \mathrm{~mm}$ incision was made approximately $10 \mathrm{~mm}$ sagittal to the midline on the left side posterior to the last rib. The entire stomach together with the spleen was pulled out through the incision with tweezers. The spleen was separated from the stomach and then returned to its original location. The constriction marking the junction between the glandular stor.ach and forestomach was tied with a ligature. An incision was made laterally to this ligature to remove the forestomach.

Removal of caecum. A $15 \mathrm{~mm}$ incision was made $10 \mathrm{~mm}$ sagittal to the midline on the right side, and starting $15 \mathrm{~mm}$ caudal to the last rib. The caecum and ampulla coli were pulled out of the incision with tweezers. The caecum was separated from the other intestines by cutting off the visceral peritoneum. A ligature was placed around the junction between the caecum and colon at the end of the ileum. An incision was made laterally to this ligature to remove the caecum.

Removal of both forestomach and caecum. A $20 \mathrm{~mm}$ incision was made approximately $5 \mathrm{~mm}$ sagittal to the midline on the left side, and starting $5 \mathrm{~mm}$ caudal to the last rib. The forestomach and caecum were removed as mentioned previously.

Sham operation. A $20 \mathrm{~mm}$ incision was made at the same place as for the removal of the forestomach and caecum. The spleen was separated from the stomach and the visceral peritoneum connecting the caecum with the small intestine was cut off.

The incisions of the stomach and caecum were washed with providone iodine solution (Meiji Seika Ltd., Tokyo, Japan). The stomach or caecum was returned to its original location. A few drops of cefazolin sodium solution (Sephalosporin Antibiotic; Fujisawa Pharmaceutical Co. Ltd., Osaka, Japan) were put into the abdominal cavity. The musculature and skin were individually sutured with ligatures and providone iodine was applied to the incision.

\section{Sample preparation and analysis}

Each sample of liver, kidney and carcass tissue was homogenized in physiological saline ( $9 \mathrm{~g}$ sodium chloride/1) $(1: 20, \mathrm{w} / \mathrm{v})$. The homogenates were quickly precipitated with one-fifth of their volume of trichloroacetic acid (500 g/l; TCA), centrifuged and washed twice with TCA ( $50 \mathrm{~g} / \mathrm{l})$ (Fürst \& Jonsson, 1971). The blood plasma protein was also precipitated by TCA as described previously. The pooled faecal samples were oven-dried at $60^{\circ}$ and analyzed in duplicate for $\mathrm{N}$ by the Kjeldahl procedure (Association of Official Analytical Chemists, 1975).

The washed protein precipitate of each tissue and blood plasma was digested by the Kjeldahl procedure and the distillate diluted with water to a volume of $100 \mathrm{ml} .50 \mathrm{ml}$ of the distillate was titrated, and the remainder was used for determination of ${ }^{15} \mathrm{~N}$. This solution was concentrated or diluted to about $200 \mu \mathrm{g} \mathrm{N} / \mathrm{ml}$ and a sample $(0.2 \mathrm{ml})$ placed in a Rittenberg's tube. It was oxidized with $\mathrm{KOBr}$ to convert ammonia to $\mathrm{N}_{2}$. The $\mathrm{N}_{2}$ was then introduced into a high vacuum discharge tube which was sealed and ${ }^{15} \mathrm{~N}$ abundance determined by emission spectrometry using an N-15 analyser (Japan Spectroscopic Co. Ltd., Tokyo, Japan).

\section{Expt 2 \\ Animals and feeding}

Random bred, 40-d-old, ma.le hamsters were allocated to the following four groups, each containing ten animals: control (sham-operated; group S), forestomach removed (group $F$ ), caecum removed (grouf $C$ ), both forestomach and caecum removed (group $F+C$ ).

Hamsters (40-d-old) were subjected to the same surgical procedures as those described for Expt 1, and housed in wire-bottom cages in groups of three or four. At $5 \mathrm{~d}$ postsurgery, the animals were housed in wire-bottom metabolism cages in groups of two, and fed the 
experimental diets for $14 \mathrm{~d}$ in the same cages. Faeces were collected daily during the last $5 \mathrm{~d}$. At the end of the experimental period, all hamsters were anaesthetized with diethyl ether, and blood was taken in a heparinized syringe from the heart.

From weaning (21-d-old) to surgery (40-d-old), hamsters were given a commercial cubed diet (ZF: Oriental Yeast Co. Ltd, Tokyo, Japan) ad lib. ZF contained (/kg) $184 \mathrm{~g}$ crude protein, $33 \mathrm{~g}$ crude fat, $139 \mathrm{~g}$ crude fibre, $71 \mathrm{~g}$ crude ash and $503 \mathrm{~g}$ NFE. After surgery, hamsters were given the cubed diet (F-1, described previously) for $5 \mathrm{~d}$. At $5 \mathrm{~d}$ postsurgery, the animals were adapted to the experimental diet containing $10 \mathrm{~g}$ urea $/ \mathrm{kg}$ and $400 \mathrm{~g}$ Italian ryegrass (Lolium italicum)/ $\mathrm{kg}$ for $5 \mathrm{~d}$. At $10 \mathrm{~d}$ postsurgery, urea in the experimental diet was replaced by $\left[{ }^{15} \mathrm{~N}\right]$ urea and the hamsters were given the $\left[{ }^{15} \mathrm{~N}\right]$ urea containing diet $(10 \mathrm{~g} / \mathrm{kg})$ for $9 \mathrm{~d}$ (Table 1$)$.

\section{Sample preparation and analysis}

Blood, liver, kidney, alimentary tract, faeces and carcass were treated as described for Expt 1. Determination of ${ }^{15} \mathrm{~N}$ in the protein fraction of the blood plasma and each tissue was carried out in the same way as in Expt 1.

\section{Statistics}

The experimental results were treated statistically by a $2 \times 2$ factorial analysis of variance (Snedecor \& Cochran, 1967). Values obtained by analysis of variance are shown in Table 6.

\section{RESULTS \\ Expt 1}

The weight gain, food consumption and digestibilities of DM, crude protein and $\left[{ }^{15} \mathrm{~N}\right]$ urea during the experimental period are shown in Table 2. During $18 \mathrm{~d}$ postsurgery, the body-weight gain showed a tendency to be lower in surgically-treated groups (groups $F$, $\mathrm{C}$ and $\mathrm{F}+\mathrm{C}$ ) as compared to the sham-operated group (group S). Values obtained by analysis of variance (Table 6) showed that the effect of removal of the caecum on the weight gain was larger than that of removal of the forestomach. The body-weight of the hamsters in all groups decreased during the first $4 \mathrm{~d}$ of the experimental period. The body-weight loss

Table 2. Expt 1. Body-weight changes, food consumption and apparent digestibilities of dry matter, crude protein (nitrogen $\times 6 \cdot 25$ ) and $\left[{ }^{15} \mathrm{~N}\right]$ urea in young male hamsters given a

$\left[{ }^{15} \mathrm{~N}\right]$ urea-containing diet

\begin{tabular}{|c|c|c|c|c|c|}
\hline Group $\ldots$ & $\mathbf{S}$ & F & $\mathrm{C}$ & $\mathbf{F}+\mathbf{C}$ & SE of mean \\
\hline No. of hamsters & 6 & 6 & 5 & 4 & \\
\hline \multicolumn{6}{|l|}{ Wt gain $(g)$ : } \\
\hline $18 \mathrm{~d}$ after surgery & $24 \cdot 5$ & $20 \cdot 4$ & $18 \cdot 3$ & $11 \cdot 3$ & $3 \cdot 0$ \\
\hline First $4 \mathrm{~d}$ of experimental period & $-11 \cdot 1$ & -9.8 & $-7 \cdot 3$ & -7.8 & 1.5 \\
\hline Last $5 \mathrm{~d}$ of experimental period & 4.5 & $2 \cdot 6$ & 0.3 & $2 \cdot 0$ & $1 \cdot 2$ \\
\hline Food consumption $(\mathrm{g})^{*}$ & $35 \cdot 3$ & 35.9 & 34.0 & $34 \cdot 0$ & $4 \cdot 3$ \\
\hline \multicolumn{6}{|l|}{ Apparent digestibility*: } \\
\hline Dry matter & 0.913 & 0.893 & 0.895 & 0.881 & 0.009 \\
\hline Crude protein & 0.884 & 0.866 & 0.849 & 0.791 & 0.016 \\
\hline$\left[{ }^{15} \mathrm{~N}\right]$ urea $\uparrow$ & 0.972 & 0.976 & 0.944 & 0.942 & 0.010 \\
\hline
\end{tabular}

S, sham-operated; F, forestomach removed; C, caecum removed; $\mathrm{F}+\mathrm{C}$, both forestomach and caecum removed.

- Values were obtained during the last $5 \mathrm{~d}$ of the experimental period.

$\dagger$ Each value is the mean for three hamsters. 
Table 3. Expt $1 .{ }^{15} \mathrm{~N}$ concentration and proportion of absorbed ${ }^{15} \mathrm{~N}$ retained in the body protein* of young male hamsters given a $\left[{ }^{15} \mathrm{~N}\right]$ urea-containing diet

\begin{tabular}{|c|c|c|c|c|c|}
\hline Group $\ldots$ & $\mathbf{S}$ & $\mathbf{F}$ & $\mathrm{C}$ & $\mathrm{F}+\mathrm{C}$ & SE of mean \\
\hline $\begin{array}{l}\text { No. of hamsters } \\
{ }^{15} \mathrm{~N} \text { concentration (atom \% excess!: }\end{array}$ & 3 & 3 & 3 & 3 & \\
\hline Carcass protein & 0.134 & 0.071 & 0.136 & 0.072 & 0.006 \\
\hline Liver protein & 0.388 & $0 \cdot 151$ & 0.424 & 0.272 & 0.052 \\
\hline Plasma protein & 0.486 & 0.213 & 0.441 & 0.220 & 0.053 \\
\hline $\begin{array}{l}\text { Accumulated }{ }^{15} \mathrm{~N} \text { in the protein of } \\
\text { carcass, liver and kidney (mg) (A) }\end{array}$ & & & & & \\
\hline $\begin{array}{l}\text { carcass, liver and kudney (mg) (A) } \\
\text { Intake }{ }^{15} \mathrm{~N} \text { (mg/hamster/9 d) (B) }\end{array}$ & $\begin{array}{l}2.776 \\
46.92\end{array}$ & $\begin{array}{l}1.364 \\
46 \cdot 53\end{array}$ & $\begin{array}{l}2 \cdot 739 \\
38 \cdot 86\end{array}$ & $40 \cdot 30$ & 3.901 \\
\hline Proportion of absorbed ${ }^{15} \mathrm{~N}$ retained $(\%)$ & & & & & \\
\hline$A /\left\{B \times\left[{ }^{15} N\right]\right.$ urea digestibility $\} \times 100$ & $6 \cdot 10$ & 2.99 & $7 \cdot 58$ & $3 \cdot 20$ & 0.50 \\
\hline
\end{tabular}

S, sham-operated; F, forestomach removed; $C$, caecum removed; $F+C$, both forestomach and caecum removed.

- Trichloroacetic acid (TCA) precipitate.

in this period occurred during the first $2 \mathrm{~d}$, and was accompanied by a decrease in food consumption. During the last $5 \mathrm{~d}$ of the experimental period, the hamsters of all groups gained body-weight. The weight gains of groups $\mathrm{F}, \mathrm{C}$ and $\mathrm{F}+\mathrm{C}$ were slightly lower than that of group $\mathrm{S}$. During this period, one hamster in group $\mathrm{C}$ and two hamsters in group $\mathrm{F}+\mathrm{C}$ had diarrhoea and died. The surgical removal of the forestomach or caecum had no influence on the food consumption. The apparent digestibility of DM and crude protein showed a tendency to be lower in the surgically-treated groups. Values obtained by analysis of variance showed that a significant lowering of the apparent digestibility of crude protein resulted from removal of the forestomach or the caecum. A significant lowering of the apparent digestibility of urea- ${ }^{15} \mathrm{~N}$ associated with removal of the caecum refers to the average effect over animals with and without their forestomachs removed.

${ }^{15} \mathrm{~N}$ concentrations and proportions of absorbed ${ }^{15} \mathrm{~N}$ retained in the body protein are shown in Table $3 .{ }^{15} \mathrm{~N}$ from $\left[{ }^{15} \mathrm{~N}\right]$ urea was incorporated into carcass, liver and blood plasma protein in all groups. The incorporation of ${ }^{15} \mathrm{~N}$ into every protein fraction of the hamsters in groups $\mathrm{F}$ and $\mathrm{F}+\mathrm{C}$ was lcwer than that of the hamsters in group $\mathrm{S}$. A significant decrease in the ${ }^{15} \mathrm{~N}$ content of body protein was produced by the removal of the forestomach, however, the removal of the caecum had no effect on the ${ }^{15} \mathrm{~N}$ content of body protein. The proportion of ${ }^{15} \mathrm{~N}$ retained in the protein fractions of the carcass, liver and kidney as a proportion of the absorbed amount decreased by half as a result of removal of the forestomach (groups $\mathrm{F}$ and $\mathrm{F}+\mathrm{C}$ ).

\section{Expt 2}

The body-weight changes during the experimental period are shown in Fig. 1. During $5 \mathrm{~d}$ postsurgery the hamsters gained weight. However, weight loss accompanying a decrease in food consumption was observed in every group during the first $5 \mathrm{~d}$ of the experimental period of urea-diet feeding. During the last $9 \mathrm{~d}$ of the experimental period, the hamsters gained weight in every group. Body-weight was lowered in the groups without caecums (C, $\mathrm{F}+\mathrm{C}$ ) compared with the groups with caecums (S, F). Up to $10 \mathrm{~d}$ postsurgery, five hamsters in group $\mathrm{S}$, four hamsters in group $\mathrm{C}$ and five hamsters in group $\mathrm{F}+\mathrm{C}$ had diarrhoea and died.

Food consumption, weight gain, food conversion efficiency and digestibilities of DM, crude protein and $\left[{ }^{15} \mathrm{~N}\right]$ urea in surgery hamsters are shown in Table 4 . The food consumption 


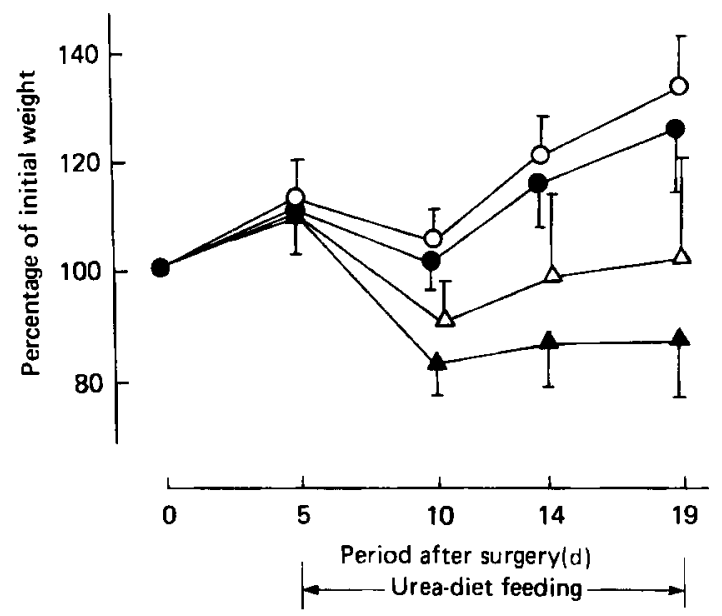

Fig. 1. Expt 2. Body-weight changes of young male hamsters during the experimental period. (O), Sham-operated $(n) ;(O)$, forestomach removed $(n$ 10); $(\Delta)$, caecum removed $(n$ 6); $(\Delta)$, both forestomach and caecum removed $(n 5)$. Points are mean values and standard deviations are represented by vertical bars.

Table 4. Expt 2. Food conversion efficiency and apparent digestibilities of dry matter, crude protein (nitrogen $\times 6 \cdot 25$ ) and $\left[{ }^{15} \mathrm{~N}\right]$ urea in young male hamsters given a $\left[{ }^{15} \mathrm{~N}\right] \mathrm{urea}-$ containing diet

\begin{tabular}{|c|c|c|c|c|c|}
\hline Group ... & $\mathbf{S}$ & F & C & $\mathrm{F}+\mathrm{C}$ & SE of mean \\
\hline No. of cages" & 5 & 5 & 5 & 5 & \\
\hline Weight gain ( $\mathrm{g}$ /hamster) $\dagger$ (A) & $12 \cdot 6$ & $16 \cdot 5$ & $2 \cdot 7$ & $5 \cdot 1$ & $2 \cdot 0$ \\
\hline Food consumption (g/hamster) + (B) & $77 \cdot 7$ & $83 \cdot 4$ & $59 \cdot 6$ & $65 \cdot 7$ & $2 \cdot 2$ \\
\hline $\begin{array}{l}\text { Food conversion efficiency (A/B) } \\
\text { Apparent digestibility: }\end{array}$ & 0.159 & 0.198 & 0.044 & 0.066 & 0.024 \\
\hline Dry matter & 0.691 & 0.706 & 0.643 & 0.635 & 0.011 \\
\hline Crude protein & 0.563 & 0.670 & 0.603 & 0.546 & 0.030 \\
\hline$\left[{ }^{15} \mathrm{~N}\right]$ urea & 0.678 & 0.812 & 0.826 & 0.749 & 0.044 \\
\hline
\end{tabular}

S, sham-operated; F, forestomach removed; $\mathrm{C}$, caecum removed; $\mathrm{F}+\mathrm{C}$, both forestomach and caecum removed.

* Each cage had one or two hamsters.

+ Values were obtained during the last $9 \mathrm{~d}$ of the experimental period.

during $9 \mathrm{~d}$ of $\left[{ }^{15} \mathrm{~N}\right]$ urea-diet feeding period was decreased significantly by removal of the caecum (groups $\mathrm{C}$ and $\mathrm{F}+\mathrm{C}$ ). The removal of the caecum resulted in a significant lowering of the food conversion efficiency which was calculated from the proportion of weight gain to food consumption. DM digestibility was also lowered by removal of the caecum (groups $C$ and $F+C$ ) but the effect of removal of the forestomach on DM digestibility was not significant. Apparent digestibility of crude protein and ${ }^{15} \mathrm{~N}$ had a comparatively large coefficient of variation in each group, and effects of surgery were not, therefore, clear cut, but the values obtained by analysis of variance showed that the interaction effects of the removal of the forestomach and caecum were statistically significant.

${ }^{15} \mathrm{~N}$ concentration and proportion of absorbed ${ }^{15} \mathrm{~N}$ retained in the body protein are shown in Table 5. The ${ }^{15} \mathrm{~N}$ concentration of the protein fractions of carcass, liver and blood plasma 
Table 5. Expt $2 .{ }^{15} \mathrm{~N}$ concentration and ${ }^{15} \mathrm{~N}$ accumulation rate in the body protein ${ }^{*}$ of young male hamsters given a $\left[{ }^{15} N\right]$ urea-containing diet

\begin{tabular}{|c|c|c|c|c|c|}
\hline Group & $\mathbf{S}$ & $\mathbf{F}$ & C & $\mathrm{F}+\mathrm{C}$ & SE of mean \\
\hline $\begin{array}{l}\text { No. of cages } \\
{ }^{15} \mathrm{~N} \text { concentration (atom \% excess): }\end{array}$ & 5 & 5 & 5 & 5 & \\
\hline Carcass protein & 0.085 & 0.059 & 0.055 & 0.048 & 0.010 \\
\hline Liver protein & 0.324 & 0.198 & 0.244 & 0.219 & 0.029 \\
\hline Plasma protein & 0.350 & 0.267 & 0.325 & 0.256 & 0.036 \\
\hline Accumulated ${ }^{15} \mathrm{~N}$ in the protein of & & & & & \\
\hline carcass, liver and kidney $(\mathrm{mg})\left(A_{2}\right)$ & 1.666 & 1.243 & 0.819 & 0.844 & 0.146 \\
\hline Intake ${ }^{15} \mathrm{~N}(\mathrm{mg} /$ hamster $/ 9 \mathrm{~d})(\mathrm{B})$ & $50 \cdot 25$ & 53.91 & $38 \cdot 51$ & $42 \cdot 48$ & 1.452 \\
\hline $\begin{array}{l}\text { Proportion of absorbed }{ }^{15} \mathrm{~N} \text { retair ed } \\
\mathrm{A} /\left\{\mathrm{B} \times\left[{ }^{15} \mathrm{~N}\right] \text { urea digestibility }\right\} \times 100\end{array}$ & 4.86 & 2.83 & 2.59 & 2.68 & 0.33 \\
\hline
\end{tabular}

S, sham-operated; F, forestomach removed; $C$, caecum removed; $F+C$, both forestomach and caecum removed.

* Trichloroacetic acid (TCA) precipitate.

Table 6. Values obtained by analysis of variance

\begin{tabular}{|c|c|c|c|c|}
\hline Expt no. & Measurement & Forestomach & Caecum & Interaction \\
\hline \multirow[t]{8}{*}{1} & Wt gain (18 d after surgery) & NS & * & NS \\
\hline & Food consumption & NS & NS & NS \\
\hline & Apparent digestibility: & & & \\
\hline & Dry matter & NS & NS & NS \\
\hline & Crude protein & * & ** & NS \\
\hline & {$\left[{ }^{15} \mathrm{~N}\right]$ urea } & NS & * & NS \\
\hline & Accumulated ${ }^{15} \mathrm{~N}$ in the body protein & ** & NS & NS \\
\hline & Proportion of absorbel ${ }^{15} \mathrm{~N}$ retained & ** & NS & NS \\
\hline \multirow[t]{9}{*}{2} & Wt gain (last $9 \mathrm{~d}$ of experimental period) & NS & ** & NS \\
\hline & Food consumption & - & *** & NS \\
\hline & Food conversion efficiency & NS & ** & NS \\
\hline & Apparent digestibility: & & & \\
\hline & Dry matter & NS & *** & NS \\
\hline & Crude protein & NS & NS & * \\
\hline & {$\left[{ }^{15} \mathrm{~N}\right]$ urea } & NS & NS & - \\
\hline & Accumulated ${ }^{15} \mathrm{~N}$ in the body protein & NS & $* *$ & NS \\
\hline & Proportion of absorbed ${ }^{15} \mathrm{~N}$ retained & ** & ** & ** \\
\hline
\end{tabular}

N5, not significant, $\bullet P<0.05, \quad * * P<0.01$.

showed a tendency to be lower in the surgical groups (groups $\mathrm{F}, \mathrm{C}$ and $\mathrm{F}+\mathrm{C}$ ) as compared with the sham-operated group (group $S$ ). The removal of the forestomach and caecum (groups $\mathrm{F}, \mathrm{C}$ and $\mathrm{F}+\mathrm{C}$ ) prciduced a large decrease in the ${ }^{15} \mathrm{~N}$ content of body protein. The removal of the forestomach and caecum also resulted in a lowering of the proportion of ${ }^{15} \mathrm{~N}$ retained in the body protein as a percentage absorbed amount in $9 \mathrm{~d}$ of the experimental period. The values obtained by analysis of variance (Table 6) showed that the role of forestomach and caecum on the utilization of urea was statistically significant. 


\section{DISCUSSION}

In Expts 1 and 2, a rapid decrease in body-weight, which was accompanied by a decrease in food consumption, was observed in the first $2 \mathrm{~d}$ of the urea-feeding period. Food consumption, however, increased after $4 \mathrm{~d}$, and all groups began to gain weight. It seems that the decrease in body-weight was mainly due to the decrease in food consumption, resulting from the abrupt change of the texture and taste of the diet and not to poor quality of the diet.

Ehle \& Warner (1978) investigated the contribution of the forestomach to the over-all nutrition of the golden hamster and they demonstrated that surgical removal of the forestomach had no effect on growth or the digestibilities of DM and crude protein. The results obtained in the present study were essentially similar to Ehle \& Warner's (1978) results. Accordingly, it was concluded that the forestomach had no critical nutritional significance for the hamster given a nutritionally-adequate diet.

The results in our experiments showed that the removal of the caecum had a marked effect on the weight gain and food conversion efficiency, and some hamsters of both groups without a caecum (groups $\mathrm{C}$ and $\mathrm{F}+\mathrm{C}$ ) had diarrhoea and died. Body-weight gain, DM digestibility and protein digestibility found in our experiments suggest that in comparison with the forestomach, the caecum may play a more important role in food utilization in the hamster, especially on a high-fibre diet.

The nutritional role of the caecum may be related to microbial digestion of ingesta in the caecum. The foundation of this hypothesis is described as follows. The hamster has a superior ability to utilize forage and to adapt its digestive organs to a forage diet (Shinohara et al. 1977), and there were more excess VFA present in the caecum than in the forestomach of the hamster which was given a forage diet. Moreover, the amount of VFA in the caecum was increased 2 to 3 times by roughage feeding compared to concentrate feeding (Manda, 1979). Furthermore, activities of enzymes of hexose monophosphate pathway involved in lipid synthesis (G6PDH, 6PGDH) in the liver were decreased with the result that malic enzyme activity was reduced in hamsters given a roughage diet, and high uptake activity of $1-\left[{ }^{14} \mathrm{C}\right]$ acetate and low uptake activity of $\mathrm{u}-\left[{ }^{14} \mathrm{C}\right]$ glucose was observed in the liver and epididymal adipose tissue of the hamster given a forage-containing diet compared to hamsters given concentrates (Murai \& Manda, 1977). These reports may indicate that VFA produced in the caecum contributes more to the energy metabolism in the hamster given a forage-containing diet than in the hamster given concentrates.

Hamsters were given a diet containing a comparatively high level of fibre after weaning and a forage-containing diet during the experimental period in Expt 2. It was observed that the forestomach and caecum of the hamster developed more on the high-fibre diet used in Expt 2 than on the low-fibre diet used in Expt 1. A similar phenomenon was reported by Manda (1979). This probably explains why the removal of the caecum had more effect on the hamster's nutrition in Expt 2 than in Expt 1.

From the fate of ${ }^{15} \mathrm{~N}$, supplied as $\left[{ }^{15} \mathrm{~N}\right] \mathrm{urea}$, it was apparent that dietary $\left[{ }^{15} \mathrm{~N}\right] \mathrm{urea}$ provided some of the $\mathbf{N}$ used in body protein synthesis in the present hamsters. The values obtained by analysis of variance (Table 6) showed that the forestomach contributed greatly to the utilization of dietary urea- $\mathrm{N}$ in both experiments. Other experiments with nonruminants have shown that the ${ }^{15} \mathrm{~N}$ from $\left[{ }^{15} \mathrm{~N}\right.$ ] urea can be incorporated into tissue protein (Bloch, 1946; Davies \& Kornberg, 1950; Liu et al. 1955; Walser \& Bodenlos, 1959; Snyderman et al. 1962; Grimson et al. 1971; Bock et al. 1976; Niiyama et al. 1978).

Deguchi et al. (1978) investigated the nutritional role of the intestinal flora in the utilization of non-protein-N (NPN) for protein synthesis by the oral administration of $\left[{ }^{15} \mathrm{~N}\right]$ urea and $\left[{ }^{15} \mathrm{~N}\right]$ diammonium citrate to germ-free and specific pathogen-free piglets. They concluded that when dietary or endogenous urea enters the intestinal tract, it is a possible 
source of $\mathbf{N}$ for protein synthesis only when the urea is converted into ammonia- $\mathrm{N}$ by the action of intestinal-bacterial urease.

The forestomach of this golden hamster has a general resemblance in histology and ultrastructure to the rumen (Sakata \& Tamate, 1976). The forestomach contents have an active microflora (Kunstyr, 1974) which produces VFA that can be absorbed from the forestomach (Hoover et al. 1969). Furthermore Matsumoto (1955) and Banta et al. (1975) have shown that the hamster is more capable of utilizing urea and is less dependent on dietary protein quality than the rat.

In a previous paper (Sakiguchi et al. 1978), it was shown that $\left[{ }^{15} \mathrm{~N}\right] \mathrm{urea}$, which was orally administered, was incorporated into the essential amino acid fraction of the forestomach contents, caecum contents and milk protein of the lactating hamster. These results suggested that microbial protein synthesis in the forestomach may have contributed to the utilization of dietary urea-N in the hanster as it does in ruminants. It seems however, that in the present studies, urea may have bersn utilized in hamsters, from which the forestomach had been removed, mostly through the pathway of formation of ammonia in the caecum and its absorption and incorporation into non-essential amino acids as described previously in single-stomached animals. This view was supported by the fact that removal of the caecum in Expt 2 decreased ${ }^{15} \mathrm{~N}$ utilization, although no similar effect was apparent in Expt 1.

Considerable amounts of microbial protein must be synthesized in the caecum. It is considered that coprophagy which is commonly found in rodents is one of the processes by which microbial protein synthesized in the large intestine may be utilized. For the incorporation of urea- $\mathrm{N}$ in:o microbial protein in the caecum, sufficient urea- $\mathrm{N}$ must reach the caecum. From the digestibility of ${ }^{15} \mathrm{~N}$, it may be inferred that sufficient $\left[{ }^{15} \mathrm{~N}\right]$ urea reached the hind gut and was available for incorporation into microbial protein in Expt 2. If the animal eats its faeces, digestion and absorption of $\left[{ }^{15} \mathrm{~N}\right]$ microbial protein may be possible. At present, it is not clear, however, whether the utilization process of $\left[{ }^{15} \mathrm{~N}\right] \mathrm{urea}$ through coprophagy is considerable or not. Removal of the forestomach might result in an increase in the amounts of urea- $\mathrm{N}$ which passed into the hind gut, and it is considered that greater amounts of urea- $\mathbf{N}$ might then be incorporated into microbial protein in the caecum.

Evidence was found for the degradation and absorption of microbial protein in the caecum of the horse (Slade et al. 19;1) and colon of the pig (Niiyama et al. 1979), and it was reported that the rat could utilize the products obtained from the digestion or degradation of the radioactive Escherichia coli placed in the caecum for the formation of lipids, protein and other carbon-containing rnaterials (Yang et al. 1972). Such results do not prove net absorption of amino acids, but suggest that the absorption of amino acids may occur in the large intestine. It is, therefore, possible that microbial protein synthesized from urea- $\mathrm{N}$ in the well developed caeclum of the hamster on the high-fibre diet can be utilized.

The digestibility of crude protein was lowered by removal of the forestomach and the caecum, and digestibility of $\left[{ }^{15} \mathrm{~N}\right]$ urea was lowered by removal of the caecum in Expt 1 . However, the effects of removal of the forestomach and caecum on the digestibility of crude protein and absorbability of ${ }^{15} \mathrm{~N}$ are not clear in Expt 2 . The results of analysis of variance showed that the interaction of forestomach and caecum was significant in relation to the digestibilities of crude protein and $\left[{ }^{15} \mathrm{~N}\right]$ urea and to the proportion of absorbed ${ }^{15} \mathrm{~N}$ retained in Expt 2. Both the forestomach and the caecum may closely interrelate in the mechanism of $\mathbf{N}$ utilization in the hamster presumably, in part, through a process of recycling $\mathbf{N}$ from caecum to forestomach. It is of interest that removal of the forestomach resulted in an increase in food consumption in Expt 2 and none of the hamsters from which forestomachs were removed died in contrast to the death of a considerable number of sham-operated hamsters. These results suggest that the forestomach may be a disadvantage in the utilization of the high-fibre diet in Expt 2.

It is considered that the difference in the effect of removal of the forestomach and the 
caecum on the utilization of urea between Expts 1 and 2 is attributable to the difference in dietary conditions. It is necessary to investigate in more detail the roles of the forestomach and caecum in the digestion and absorption of food ingredients under different dietary conditions.

The authors express their thanks to Dr T. Manda and Dr N. Takano of the National Grassland Research Institute, for their generosity and co-operation in providing facilities and materials for the performance of Expt 2.

The present work was supported in part by a grant-in-aid (No. 556209) for scientific research from the Ministry of Education, Japan.

\section{REFER E NCES}

Association of Official Analytical Chemists (1975). Official Methods of Analysis of the Association of Analytical Chemists, 12th ed. Washington: Association of Official Analytical Chemists.

Banta, C. A., Warner, R. G. \& Robertson, J. B. (1975). J. Nutr. 105, 38.

Bloch, K. (1946). J. biol. Chem. 165, 469.

Bock, H. D., Kowa, J., Krawielitzki, K., Völker, T., Wünsche, J. \& Zebrowska, T. (1976). Arch. Tierernähr. 26, 777.

Davies, R. E. \& Kornberg, H. L. (1950). Biochem. J. 47, viii.

Deguchi, E., Niiyama, M., Kagota, K. \& Namioka, S. (1978). J. Nutr. 108, 1572,

Duncan, D. B. (1955). Biometrics 11, 1.

Ehle, F. R. \& Warner, R. G. (1978). J. Nutr. 108, 1047.

Fürst, P. \& Jonsson, A. (1971). Acta chem. scand. 25, 930.

Grimson, R. E., Bowland, J. P. \& Milligan, L. P. (1971). Can. I. Anim. Sci. 51, 103.

Harper, A. E. (1959). J. Nutr. 68, 406.

Hoover, W. H., Mannings, C. L. \& Sheerin, H. E. (1969). J. Anim. Sci. 28, 349.

Imai, S., Lap, H. T. \& Ogimoto, K. (1976). Jap. J. Parasit. 25 Suppl. 83.

Kunstyr. I. (1974). Zentbl. VetMed. 21A, 553.

Liu, C. H., Hays, V. M., Svec, H. J., Catron, D. V., Ashton, G. C. \& Speer, V. G. (1955). J. Nutr. 57, 241.

Manda, T. (1979). Jap. Agric. Res. Quart. 13, 110.

Manda, T. \& Takano, N. (1976). J. Jap. Grassld. Sci. 22, 46.

Matsumoto, T. (1955). Tohoku J. agric. Res. 6, 127.

Murai, M. \& Manda, T. (1977). Exp. Herbivora 2 Suppl., 70.

Niiyama, M., Deguchi, E., Kagota, K. \& Namioka, S. (1979). Am. J. vet. Res. 40, 716.

Niiyama, M., Kagota, K., Iwase, T. \& Namioka, S. (1978). Jap. J, vet. Sci. 40, 575.

Sakaguchi, E., Horiguchi, M. \& Matsumoto, T. (1978). Jap. J. zootech. Sci. 49, 653.

Sakata, T. \& Tamate, H. (1976). Tohoku J. agric. Res. 27, 26.

Shinohara, H., Kayaba, T. \& Mizuma, Y. (1977). Exp. Herbivora 2 suppl, 29.

Slade, L. M., Bishop, R., Morris, J. G. \& Robinson, D. W. (1971). Br. vet. J. 127, xi.

Snedecor, G. W. \& Cochran, W. G. (1967). Statistical Methods, 6th ed. Ames: lowa State University Press.

Snyderman, S. E., Holt, L. E. Jr, Dancis, J., Roitman, E., Boyer, A. \& Balis, M. E. (1962). J. Nutr. $78,57$.

Tseng, R. Y. L., Cohen, N. L., Reyes, P. S. \& Briggs, G. M. (1976). J. Nutr. 106, 77.

Walser, M. \& Bodenlos, L. J. (1959). J. clin. Invest. 38, 1617.

Yang, M. G., Bergen, W. G., Sculthorpe, A. E. \& Mickelsen, O. (1972). Proc. Soc. exp. Biol. Med. $139,1312$. 